\title{
The labor market reintegration of returned refugees in Afghanistan
}

\author{
Craig Loschmann • Katrin Marchand
}

\begin{abstract}
Even though Afghanistan remains one of the top origin countries of refugees around the world, a considerable number of refugees have also returned over the last three decades. This paper investigates the labor market outcomes of those returned refugees from Iran and Pakistan, motivated by the fact that their reintegration greatly depends on the ability to access sustainable income-generating activities as a basis of their livelihood. The analysis relies on cross-sectional data from an original household survey collected in five provinces of Afghanistan in 2011. The analytical approach is twofold: first, to compare returned refugees to non-migrants in regard to what influences their respective labor market outcomes; and second, to investigate the influence of the returnees' migration and return experience on those outcomes. We find evidence that returned refugees are less likely to be wage employed in comparison to nonmigrants and that those factors related to socioeconomic status including educational attainment, and the strength of social networks plays an influential role in labor market outcomes. When it comes to the migration and return experience of returnees, a few key factors are found to be of particular consequence for current employment status including employment prior to migration, time abroad, amount of savings brought back upon return, return assistance, and intentions to re-migrate.
\end{abstract}

C. Loschmann · K. Marchand $(\bowtie)$

Maastricht Graduate School of Governance | UNU-MERIT, Maastricht University, Boschstraat 24, 6211 AXMaastricht, the Netherlands

e-mail: k.marchand@maastrichtuniversity.nl
These findings help to shed light on the reintegration process of returned refugees in Afghanistan, an issue of growing concern for policymakers taking into consideration the recent increase in return flows.

Keywords Refugees · Return migration · Repatriation · Labor market $\cdot$ Reintegration $\cdot$ Afghanistan

JEL classification $\mathrm{F} 22 \cdot \mathrm{J} 15 \cdot \mathrm{J} 24 \cdot \mathrm{J} 61 \cdot \mathrm{J} 62 \cdot \mathrm{L} 26 \cdot \mathrm{O} 53$

\section{Introduction}

The topic of migration continues to receive considerable attention as of late both within high level policy circles and across popular media. This heightened interest is in large part due to the impression that we are living in times of unprecedented forced displacement, driven by the fact that the absolute number of people in exile both within and outside their countries of origin remains at a modern-day high (UNHCR 2018a). It is important to keep perspective, however, and consider that the relative number of refugees compared to the world's population remains small and mostly stable (de Haas 2016). Still, at the more local level, certain countries predominately in the "Global South" are indeed facing significant pressure to cope with refugee populations. While it is difficult to estimate just how many of today's refugees will be integrated into their host societies, an important consideration over the medium- and long-term is their potential return back to their countries of origin. Just as the influx of refugees from elsewhere may have important 
development-related consequences for a local community, so too can the sudden arrival of returnees who may have spent years, if not lifetimes, abroad.

Only recently has return migration begun to gain interest among academic scholars and policymakers as evidence mounts that the knowledge, skills, and savings acquired abroad and subsequently transferred upon return have the potential to contribute to positive development outcomes. For this potential to be realized, however, the manner in which returnees reintegrate into their communities, including into the labor market, is fundamental. In this regard, certain case studies on record have found that return migrants are more likely than non-migrants to be self-employed rather than employed as wage labor (Piracha and Vadean 2010; Wahba and Zenou 2012). Yet such an observation is ultimately ambiguous without a qualified understanding of the greater context under study, including the underlying causes of migration in the first place. The majority of studies looking at labor market outcomes of returnees focus mainly on countries characterized by voluntary labor migration. Very few offer insights into the livelihood activities of returned refugees in (post-)conflict environments.

With this in mind, this paper investigates the labor market outcomes of returned refugees in Afghanistan. Even though Afghans today still make up one of the largest refugee populations outside their country, Afghanistan has also experienced significant return migration at various intervals over the last three decades. Figure 1 illustrates, for example, how the Taliban's ouster in 2001 resulted in the sudden return of 2 million refugees and another 3.6 million in the immediate years following. While return flows tapered off around 2006, the yearly figure of officially returned refugees in 2016 was back up to levels not seen since then. In fact, the estimated 385,000 individuals repatriated throughout 2016 are more than fivefold increase relative to the year prior, and IOM (2017) believes there may have been be an additional 690,000 undocumented returnees.

This study is motivated by the fact that the reintegration of returned refugees in a (post-)conflict setting like Afghanistan greatly depends on the ability to access sustainable income-generating activities as a basis of their livelihood. The analysis relies on cross-sectional data from an original household survey collected in five provinces of Afghanistan in 2011. The analytical approach is twofold: first, to compare returned refugees to non-migrants in regard to what influences their respective labor market outcomes; and second, to investigate the influence of the returnees' migration and return experience on those outcomes. Because we are interested in the labor market reintegration of returned refugees, we only take into consideration those returnees who originally migrated because of political or security concerns or because of an environmental disaster. And while recent reports highlight the increasingly involuntary nature of return for many Afghan refugees and asylum-seekers (see, e.g., Human Rights Watch 2017; Bjelica and Ruttig 2017), our sample is made up of returnees from Iran and Pakistan who chose to return because of perceived improvements to the political and security situation in the country or due to a variety of personal reasons (e.g., missed country, culture, or family). None returned because of work-related opportunities, helping to isolate our estimates from selection bias. The sample ultimately covers 1841 individuals, of which 461 are returned refugees.

The results indicate that returned refugees in Afghanistan are less likely to be wage employed in comparison to non-migrants. Differences in labor market outcomes arise from dissimilarities in socioeconomic status including educational attainment and the strength of social networks. As for the influence of the migration and return experience on employment status, a few key factors are found to be of consequence. First and somewhat expected, being employed prior to migrating helps raise the likelihood of being wage employed upon return. Less expected, however, given the context of forced migration, the more years spent abroad the greater the odds of being wage employed, indicating skill acquisition while abroad. Moreover, the amount of savings brought back upon return is positively associated with becoming self-employed in agriculture or herding (i.e., subsistence farming), while the opposite is true if the individual received assistance upon return or has intentions to re-migrate.

From a scholarly perspective, this study contributes to the academic discussion in a variety of ways. For one, the empirical evidence on refugee return and reintegration into the labor market is relatively limited. Even though descriptive accounts of certain contexts provide insight (see, e.g., Mesic and Bagic 2011; ILO 2013), none to the best of our knowledge take a quantitative methodological approach. One clear reason for this is the fact that large-scale data sets covering conflictaffected environments such as Afghanistan are generally rare. That we are able to rely on relatively uncommon 
Fig. 1 Refugees and returned refugees in Afghanistan. Source: UNHCR 2018b. The number of "Refugees" indicates the stock of the population from Afghanistan, while the number of "Returned refugees" indicates flows within the calendar year (i.e., JanuaryDecember).

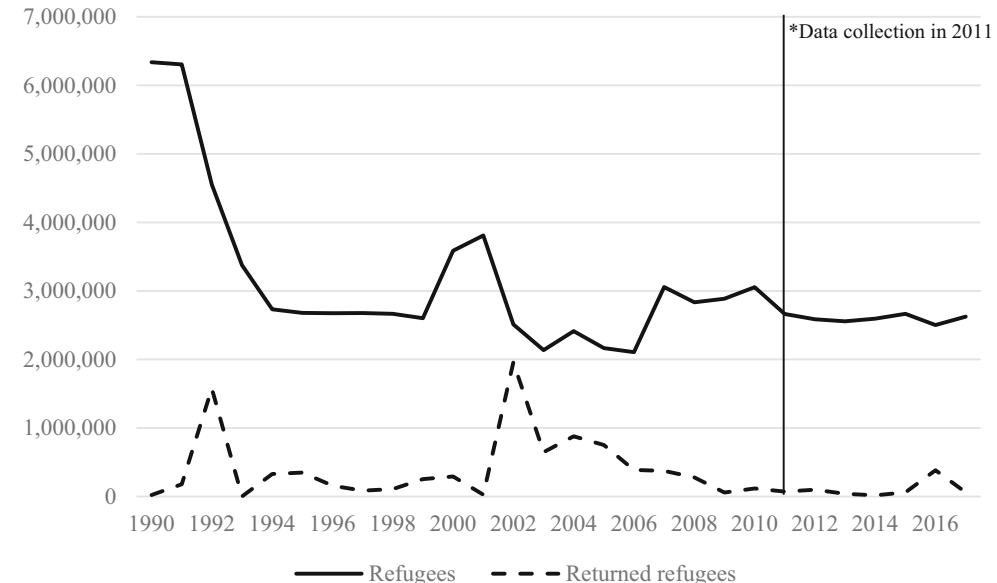

primary data in this context provides us with a unique opportunity to investigate the labor market reintegration of returned refugees. Furthermore, by investigating labor market outcomes, including self-employment in business, of both returned refugees and non-migrants, the study contributes more generally to the literature on labor markets in (post-)conflict settings. Such analysis is important considering the linkages that have been drawn in the literature between employment creation, economic growth, and stabilization after conflict (see, e.g., Collier 2009; Cramer 2015).

The remainder of this paper is structured as follows. The next section provides a review of the relevant literature concerning return migration and the dynamics related to labor market outcomes upon return. This is followed by a more detailed account of the methodology including the empirical approach and sample. We finally present the results and conclude with a brief summary and policy discussion concerning ways to support returned refugees in Afghanistan in their labor market reintegration.

\section{Literature review}

In a (post-)conflict setting still fraught with lingering uncertainty about the future, the sustainability of return and reintegration is often a challenging process (Bascom 2005). Reintegration takes time and for some returnees is never achieved, often resulting in re-migration (Kuschminder 2013). Many factors contribute to a successful return and reintegration, including a welcoming community, security, access to basic infrastructure and services, and the chance to make a decent living. A robust local labor market providing job opportunities and livelihood possibilities therefore greatly influences whether or not a returnee chooses to settle permanently again at origin (Black and Gent 2006).

At the same time, conflicts have significant impacts on labor markets and change the types of employment opportunities available (Stewart 2015). A common feature of conflict is an observed reallocation of employment, largely depending on the development of said conflict. Where infrastructure such as power plants or fuel facilities is destroyed, for example, major providers of employment disappear. Equally, trade and tourism tend to be affected by conflict and impact employment opportunities in related sectors (Cramer 2015). More generally, labor markets in developing countries often leave individuals to decide between engagement in self-employment activities, agriculture, household work, or migration due to a scarcity of wage-employment opportunities, particularly in rural regions (Nagler 2015).

The role of small businesses and self-employment, especially in the informal sector, therefore has received specific attention within these discussions highlighting the importance of such activities in the context of developing countries in terms of employment and income generation (Zenou 2008). While self-employment in such contexts may intrinsically be subsistence-based, it is helpful to consider such an activity in relation to entrepreneurship, which more often than not is associated with positive changes such as job and wealth creation, innovation, and related welfare effects (Ács 2006; Desai 2011; Naudé 2010b). Desai (2011), for example, argues that entrepreneurship creates bottom-up activities addressing immediate and short-term problems. Naudé 
(2010a), on the other hand, believes that entrepreneurs drive the structural transformation of an economy away from agriculture and toward manufacturing and services. Beyond these macro-level effects, small businesses may also simply be a viable survival strategy when institutional support mechanisms are lacking (Ciarli et al. 2010). In this respect, it is necessary to make the distinction between opportunity and necessity entrepreneurship. Whereas opportunity entrepreneurs are thought to seize unique opportunities in the market, necessity entrepreneurs engage in entrepreneurial activities because it is the best or only option available (Reynolds et al. 2005). According to Margolis (2014), roughly two thirds of self-employment in developing countries is due to a lack of other alternatives for income-generation. Even though entrepreneurship based on opportunity may be preferred, the activities of necessity entrepreneurs are still important to consider in a context like that of Afghanistan, as such enterprises provide at least one livelihood and have the potential to contribute to local development (Ciarli et al. 2010).

When it comes to finding a suitable activity in the labor market, three primary types of capital are essential: human, financial, and social. Human capital describes natural characteristics like intelligence and health but also skills and abilities acquired mainly through education and work experience (Bosma et al. 2004). Financial capital principally consists of personal savings as well as private and public loans either from friends and family, a financial institution, or the government. And social capital embodies an individual's relationships to others and the network on which one can rely (Westlund and Bolton 2003). With all, return migrants are often believed to have a distinct advantage in comparison to their non-migrant counterparts (Black et al. 2003). Beyond the potentially innate differences regarding risk aversion and the like, returnees often had sent or come back with substantial savings accumulated while abroad to be consumed and/or invested once back (OECD 2008). Moreover, returnees might arrive with additionally acquired education or skills useful to local markets (Cassarino 2004). Lastly, in many cases, spending time abroad exposes one to a diverse set of social networks potentially providing a returnee with a greater number of links and therefore opportunities beyond the community once back. On the other hand, migrating in the first place may lead to a loss in contact with local networks which may put returnees at a disadvantage with respect to local opportunities (Klagge et al. 2007).
With this conceptual framework at hand, a number of empirical studies focusing on voluntary migration have made an effort to identify the labor market activities of returnees and more specifically the factors leading to self-employment and small business establishment. With regard to human capital, there is ample evidence that points to its importance in finding employment and for the small business creation by returnees. Looking at Turkish returnees from Germany, Dustmann and Kirchkamp (2002) find evidence of education as a driving factor in self-employment. In this case, those with a higher level attained have a greater probability of opening a business compared to non-participation, likely due to expected positive returns of education increasing the likelihood of choosing such an activity. Borodak and Piracha (2011) confirm such finding when it comes to returning Moldovans yet explain that those at a lower skill level are unable to afford being without a formal source of income leading to the greater likelihood of wage employment. Conversely, however, Ilahi (1999) and McCormick and Wahba (2001) show that returnees with higher levels of education are more likely to be wage employed rather than self-employed in the case of Pakistan and Egypt, respectively. Still, additional evidence in the latter case suggests that the length of employment while abroad also positively influences the odds of becoming self-employed upon return, an outcome corroborated elsewhere (McCormick and Wahba 2001; Black and Castaldo 2009; Wahba and Zenou 2012). Therefore it appears as Tani and Mahuteau (2008) show in their study of returnees to North Africa that the practical experiences and skills gained abroad play a crucial role in determining selfemployment, while formal education is more likely to lead to wage employment even if it also decreases the chance of unemployment.

The most common finding concerning selfemployment relates to financial capital and more specifically the role of savings accumulated abroad in the launch of a small business upon return. For instance, both Arif and Irfan (1997) and Piracha and Vadean (2010) find strong indication that return migrants are more likely to be self-employed in business in comparison to non-migrants precisely because they had the opportunity to gather start-up capital abroad. Focusing exclusively on return migrants, Ilahi (1999), Dustmann and Kirchkamp (2002), and Mesnard (2004) arrive at a similar conclusion showing return migrants are prone to invest savings from abroad in business ventures back 
home, suggesting temporary migration may at times be employed as a strategy to overcome credit constraints faced in the country of origin. While in the context of forced migration, this strategy is less applicable, and it may still be the case that migrants are able to accumulate savings abroad that they can indeed utilize upon return to the home country.

Finally, when it comes to social capital, personal networks play a significant role in the reintegration of return migrants in the home country (Omata 2012). The role networks play in the labor market reintegration of returnees is on the other hand empirically unclear. Black and Castaldo (2009), for instance, find that the strength of personal linkages, measured by membership in an association in the host country and visits home, does have a positive effect on business start-ups of return migrants in both Ghana and Côte d'Ivoire. Conversely, Piracha and Vadean (2010) show in the case of Albania no evidence of social capital, proxied by the number of friends one has, having any impact on the occupational choice of return migrants despite there being a significant effect for non-migrants. Going one step further, Wahba and Zenou (2012) model the potential trade-off between the financial and human capital accumulated while abroad against the social capital lost due to moving in the first place. In the context of Egypt, they provide evidence that gains in both financial and human capital which play a significant role in the choice of selfemployment upon return, whereas a loss in social capital has no impact on returnees to become entrepreneurs even if it does for non-migrants. In all, the role of social capital largely depends on the specific local context as well as the type of employment activity. Return migrants may have comparative advantages in sectors where foreign networks are specifically beneficial, while nonmigrants may benefit from having stronger local networks where those are most important.

Although at times differing, overall the existing studies indicate that the migration experience greatly influences labor market outcomes of return migrants once back in the country of origin. Still, these experiences are not uniform as some individuals are inherently presented with greater opportunities abroad and therefore greater job prospects upon return (Arif and Irfan 1997; Gubert and Nordman 2011; Kilic et al. 2009). In a study of returnees in seven capital cities in Western Africa, for example, de Vreyer et al. (2010) show that there are significant differences in the uptake of an entrepreneurial activity upon return depending on the country of migration. In particular, they find those who returned from OECD countries in comparison to non-OECD countries are more likely to be entrepreneurs due to the better chances to accumulate financial and human capital at those destinations. Additionally, differences in the environment to which the migrant returns also play an important role. As such, it is important to better understand the labor market activities of returned refugees in particular (post-)conflict settings, in order to promote conditions that facilitate sustainable return and reintegration processes in such contexts.

\section{Methodology}

\subsection{Empirical approach}

As indicated prior, our objective is twofold: first, to compare returned refugees to non-migrants in regard to what influences their respective labor market outcomes; and second, to investigate the influence of the returnees' migration and return experience on those outcomes. In both cases, we employ a multinomial logit model to estimate the propensity that an individual is engaged in one of the three labor market activities compared to the base alternative of not working ${ }^{1}$. The three activities include self-employment in business, agriculture which incorporates subsistence farming and/or animal herding, and wage employment. The model can be expressed as:

$$
\operatorname{Pr}\left(y_{i}=j\right)=\frac{e^{\beta_{j} x_{i}}}{\sum_{k=1}^{K} e^{\beta_{k} x_{i}}}
$$

where $y_{i}$ represents activity $j$ of individual $i$. On the right-hand side of the equation, the $x_{i}$ vector incorporates a range of individual, household, and community characteristics, as well as migration- and return-related characteristics when looking exclusively at returnees, and $\beta_{j}$ represents the vector of activity-specific coefficients.

Prior to estimating the model, it is important to consider the possibility of self-selection. As has been established in the literature, there is reason to believe that both migrants and returnees may be intrinsically

\footnotetext{
${ }^{1}$ Not working refers to individuals unemployed and actively looking for work, as well as individuals unemployed and wanting a job but not actively looking.
} 
different from non-migrants based on unobservable characteristics that are correlated with employment status. Most of the evidence in this regard pertains to labor migration and the prospect that migrants are inherently more intrepid and thus less risk averse than the nonmigrant population and that return migrants may have picked up informal skills and expertise during their time abroad (Dustmann and Kirchkamp 2002; OECD 2008, 2010; Borodak and Piracha 2011). Similarly, migrants may return only when they believe that the prospects for employment have improved to their advantage (Novak 2007; Hautaniemi et al. 2013). As discussed prior, our sample is limited to only those returnees who originally migrated because of political or security concerns or because of an environmental disaster and who stated their return was motivated by improvements to the political and security situation of the country or a variety of personal reasons (e.g., missed country, culture, or family). ${ }^{2}$ We believe that by excluding voluntary migrants, and the few returnees motivated by employment opportunities, our estimates are less afflicted by selection bias than would otherwise be the case. Nonetheless, even in a context of systematic insecurity, there may be inherent differences between those able to migrate, as well as those deciding to return. The estimates, therefore, may still potentially suffer from positive selfselection and should be interpreted with caution. However, under such conditions, one can assume such bias would lead to inflated estimates and as a result can be considered upper bounds.

\subsection{Sample}

The data used for the analysis comes from an original household survey implemented across Afghanistan in 2011, for the IS Academy "Migration \& Development: A World in Motion" project. ${ }^{3}$ Although not nationally representative due to difficulties surveying in high risk locations, the sampling incorporated households of differing fundamental characteristics in order to increase overall representativeness. More specifically, the five provinces of Kabul, Herat, Balkh, Nangarhar, and

\footnotetext{
2 The percentage of all returnees who indicated their original migration episode was voluntary is around a quarter of the original sample, while the percentage of all returned refugees who indicated they returned for employment opportunities is less than $1 \%$.

${ }^{3}$ For more information on the IS Academy project, as well as sampling methodology in the case of Afghanistan, see: <https://www.merit.unu. edu/themes/6-migration-and-development/is-academy/>.
}

Kandahar were selected because of their highly populated urban centers, geographical dispersion, and varied profiles of migration. Within each province, a stratification of districts was applied based on whether they were considered urban, semirural, or rural. ${ }^{4}$ This stratification allowed for greater representation of different socioeconomic groups, and districts were chosen based on their representativeness of the province at large. The primary sampling units were then selected at random taking into consideration a detailed list of specific sites for enumeration provided by the Afghan Central Statistics Office. In all, ten communities within an urban area and five from each of the semirural and rural areas were selected for enumeration. Within the communities, the absence of any official household listing made it necessary for the team leader to discuss the rough makeup of the community with a local leader or elder prior to enumeration. This led to a general distributional profile of the community based on current migrant, return migrant, and non-migrant households which was then respected throughout enumeration in order to be as representative as possible. Finally, the selection of households followed a random starting point and fixed interval sampling strategy in order to meet the pre-specified quota in each community. Ultimately, the survey covered a total 14,777 individuals within 2005 households across 100 distinct communities.

Once excluding individuals outside the working age of 15-65, inactive on the labor market, females and returnees who migrated voluntarily, as well as returned before 1992, we are left with a sample of 1841 respondents of which 461 are returned refugees. ${ }^{5}$ Table 1 provides the summary statistics of the sample, differentiated by migration status. We report a mean difference test in the final column, which only applies to those variables applicable to both non-migrants and returnees. When comparing non-migrants to returned refugees based on the labor market outcome variable of interest, we find little difference between the two groups. Returnees, on

\footnotetext{
${ }^{4}$ Urban refers to those communities which are the district capital; semirural refers to those communities which share a common border with the district capital; and rural refers to those communities with no common border with the district capital.

${ }^{5}$ We look at male respondents that only given women's labor force participation in Afghanistan is systematically lower than that of men (CSO 2014). We exclude inactive individuals, for example, retired or permanently sick/disabled. We do not consider individuals who returned prior to 1992 because of differences to the political climate prior to the fall of the Najibullah regime in that year. These individuals account for only $8 \%$ of all returnees in the original sample.
} 
average, are about six percentage points more likely to be self-employed in business, whereas non-migrants are around five percentage points more likely to be wage employed, with the mean differences significant at the $10 \%$ level. There is no statistical mean difference between not working and being engaged in agricultural activity.

As for fundamental demographic characteristics, there are considerable differences in terms of household position and age as nearly all returned refugees are the household head in comparison to around half of nonmigrants, and the average difference in age between the two groups is 8 years. Likewise, returnees are more likely to be married in comparison to non-migrants, as well as have more children. Regarding educational attainment, a proxy for human capital, there is only a marginal statistical difference between the two groups with around $15 \%$ of returnees having a secondary or higher level of education compared to $11 \%$ of nonmigrants. In terms of socioeconomic status, there is no discernable difference between groups based on land ownership. Still, returned refugees are on average 12 percentage points more likely to have social capital in the form of a local social network, indicated by involvement in a community organization other than a religious group.

In looking at some of the migration-related characteristics for returned refugees only, a quarter of returnees were employed prior to migrating and just over twothirds migrated to Pakistan, while the rest went to Iran. ${ }^{6}$ The average time abroad is around 12 years, and only $6 \%$ sent remittances during that period. In terms of the return experience, around half repatriated between the fall of the Najibullah regime in 1992 and the ouster of the Taliban regime in 2001, corresponding to the average of 10 years since return. Nearly three-fourths of returnees cited improvements in the political and/or security situation as the main reason for return, while the rest reported personal reasons (i.e., wanting to be closer to my family and friends). Looking at the financial capital of returned refugees, the average amount of savings brought back upon return is 246 USD, and $28 \%$ received support upon return in the form of financial assistance by either an international organization or the

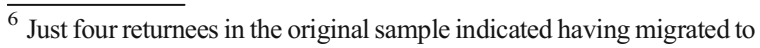
and returned from a country outside of Pakistan or Iran (i.e., England, UAE, Saudi Arabia, and Tajikistan). However, none of those observations are included in the final sample used for analysis following the aforementioned exclusion criteria.
}

government. Lastly, only $19 \%$ of returnees have concrete intentions to re-migrate in the future.

\section{Results}

In presenting our empirical results, we begin with a simple examination of whether being identified as a returned refugee makes an individual more likely to be involved in one of the three labor market activities in comparison to not working. In all models hereafter, we report the relative risk ratios along with robust standard errors in parentheses. And aside from the sociodemographic covariates presented in the tables, all models control for the ethnicity (i.e., Pashtun, Tajik, other $^{7}$ ) of the returnee as well as the district type (i.e., urban, semirural, or rural) and province of return.

Table 2 shows that when controlling for basic sociodemographic characteristics, a returned refugee is on average less likely to be involved in agricultural activity as well as wage employment holding all else constant. More specifically, for returned refugees relative to nonmigrants, the relative risk of being wage employed is less likely by a factor of 0.42 . While the same relationship holds for self-employment in business, the result is significant at the $10 \%$ level. Taking into consideration the potential for positive self-selection as previously discussed, these estimates can be considered upper bounds, meaning the negative effect may be even greater than is found here.

Expecting differences between non-migrants and returned refugees, we conduct a Chow test to rule out the null hypothesis of similar coefficients across the two groups. The results of the test show a statistically significant chi-square value for both self-employment in business and wage employment. This indicates that the estimated coefficients between groups are statistically different and individual covariates in our model influence non-migrants and returnees differently for both labor market categories. The estimated coefficients for agriculture, on the other hand, are not statistically different between both groups, suggesting return migration may not be influential for this activity.

Table 3 compares non-migrants and returned refugees in regard to what influences their respective labor

\footnotetext{
${ }^{7}$ The original questionnaire included more ethnic groups (e.g., Uzbek, Hazara, Turkmen and Baloch); however, the limited number of each in the sample led us to group these into one "other" category.
} 
Table 1 Summary statistics, comparing non-migrants to returned refugees

\begin{tabular}{|c|c|c|c|c|c|}
\hline & \multicolumn{2}{|c|}{ Non-migrant } & \multicolumn{2}{|c|}{ Returned refugees } & \multirow[b]{2}{*}{ t-test } \\
\hline & Mean & $\mathrm{Sd}$ & Mean & $\mathrm{Sd}$ & \\
\hline \multicolumn{6}{|l|}{ Labor market activity: } \\
\hline Not working & 0.1638 & 0.3702 & 0.1475 & 0.3550 & \\
\hline Self-employment & 0.4362 & 0.4961 & 0.4989 & 0.5005 & $*$ \\
\hline Agriculture & 0.1362 & 0.3432 & 0.1410 & 0.3484 & \\
\hline Wage employment & 0.2638 & 0.4408 & 0.2126 & 0.4096 & $*$ \\
\hline \multicolumn{6}{|l|}{ Socio-demographic covariates } \\
\hline Head of $\mathrm{HH}$ & 0.5043 & 0.5002 & 0.9306 & 0.2544 & $* * *$ \\
\hline Age & 32.57 & 14.17 & 41.30 & 12.09 & $* * *$ \\
\hline Married & 0.5920 & 0.4916 & 0.9393 & 0.2391 & $* * *$ \\
\hline Number of children & 2.90 & 1.95 & 3.28 & 1.88 & $* * *$ \\
\hline \multicolumn{6}{|l|}{ Education attainment: } \\
\hline Lower than secondary & 0.8884 & 0.3150 & 0.8482 & 0.3593 & $*$ \\
\hline Secondary or higher & 0.1116 & 0.3150 & 0.1518 & 0.3593 & $*$ \\
\hline HH owns land & 0.2290 & 0.4203 & 0.2234 & 0.4170 & \\
\hline Community involvement & 0.6812 & 0.4662 & 0.7983 & 0.4017 & $* * *$ \\
\hline \multicolumn{6}{|l|}{ Migration and return covariates } \\
\hline Employed pre-migration & & & 0.2581 & 0.4381 & \\
\hline \multicolumn{6}{|l|}{ Migration destination: } \\
\hline Pakistan & & & 0.7115 & 0.4536 & \\
\hline Iran & & & 0.2885 & 0.4536 & \\
\hline Migration duration (years) & & & 12.32 & 7.58 & \\
\hline Remittances sent & & & 0.0564 & 0.2309 & \\
\hline \multicolumn{6}{|l|}{ Return period: } \\
\hline $1992-2001$ & & & 0.5141 & 0.5003 & \\
\hline 2002-2011 & & & 0.4859 & 0.5003 & \\
\hline Time since returned (years) & & & 10.26 & 5.03 & \\
\hline Return reason: political/security & & & 0.7223 & 0.4483 & \\
\hline Return savings (USD) & & & 246.19 & 889.54 & \\
\hline Return assistance & & & 0.2842 & 0.4515 & \\
\hline Re-migration intentions & & & 0.1887 & 0.3917 & \\
\hline
\end{tabular}

Significance levels: $* p<0.10, * * p<0.05, * * * p<0.01$

market activity. First, we notice statistically significant similarities in terms of basic demographic characteristics. For instance, being the head of the household and married makes an individually more likely to be employed in nearly all three categories compared to not working for both non-migrants and returnees. Alternatively, the older an individual, the slightly less prone they are to be self-employed in business or wage employed, regardless of migration status. Only in the case of returnees are these characteristics not relevant for being involved in agriculture.
As for educational attainment, the results paint a mixed picture. Non-migrants with a higher level of educational attainment (i.e., at least secondary schooling) are less likely to be engaged in agricultural work and more likely to be involved in wage labor. For returned refugees, however, statistical significance drops out for wage employment. This suggests that non-migrants with low levels of education have few options other than subsistence agricultural labor, whereas relatively higher levels of education open up opportunities for wage labor. Conversely, the prospect of 
Table 2 Labor market activity

\begin{tabular}{|c|c|c|c|}
\hline Base: not working & Self-employment & Agriculture & Wage employment \\
\hline \multirow[t]{2}{*}{ Returned refugee } & $0.7093 *$ & $0.5800 * *$ & $0.4169 * * *$ \\
\hline & -0.1417 & -0.1515 & -0.0913 \\
\hline \multirow[t]{2}{*}{ Head of $\mathrm{HH}$} & $4.6679 * * *$ & $5.1664 * * *$ & $4.8012 * * *$ \\
\hline & -1.1397 & -1.6244 & -1.2508 \\
\hline \multirow[t]{2}{*}{ Age } & $0.9438 * * *$ & $0.9634 * * *$ & $0.9484 * * *$ \\
\hline & -0.0073 & -0.0092 & -0.0079 \\
\hline \multirow[t]{2}{*}{ Married } & $3.1273 * * *$ & $3.0185 * * *$ & $2.3338 * * *$ \\
\hline & -0.7458 & -0.9691 & -0.5853 \\
\hline \multirow[t]{2}{*}{ Number of children } & 0.9571 & 0.9949 & 0.9839 \\
\hline & -0.0385 & -0.051 & -0.0421 \\
\hline \multirow[t]{2}{*}{ Education: secondary or higher } & $0.6412 * *$ & $0.2429 * * *$ & $2.4956^{* * *}$ \\
\hline & -0.1449 & -0.1071 & -0.5743 \\
\hline \multirow[t]{2}{*}{ HH owns land } & 1.053 & $5.0329 * * *$ & 0.9316 \\
\hline & -0.2051 & -1.1382 & -0.1926 \\
\hline \multirow[t]{2}{*}{ Community involvement } & $2.2726^{* * *}$ & $2.6145 * * *$ & $2.1635 * * *$ \\
\hline & -0.3962 & -0.6345 & -0.3945 \\
\hline Pseudo-R ${ }^{2}$ & 0.2080 & & \\
\hline $\mathrm{N}$ & 1841 & & \\
\hline
\end{tabular}

Significance levels: $* p<0.10, * * p<0.05, * * * p<0.01$. Relative risk ratios are reported, with robust standard errors in parentheses. The reference group for educational attainment is "lower than secondary." Other controls not reported include "Ethnicity," "District type," and "Province"

wage employment for returned refugees has less to do with their level of education.

With respect to household socioeconomic characteristics, as to be expected, both non-migrants and returned refugees within households owning land have a higher likelihood of being engaged in an agricultural activity relative to not working. More interestingly, the strength of social networks, proxied for by involvement in a community organization, appears to be similarly relevant for both non-migrants and returned refugees across all labor market outcomes.

Table 4 reports the differences across labor market activities based on the migration and return experience of returned refugees only. Nearly all of those same individual and household characteristics influential in the previous model are once again statistically significant, so as a matter of parsimony, only the migrationand return-related characteristics of interest are presented here. First, and somewhat expectedly, we find that those individuals who were employed prior to migrating have a higher likelihood of being wage employed in comparison to not working upon return. Less expected, however, given the context of forced migration, the more years spent abroad, the slightly greater the likelihood of being wage employed indicating a degree of skill acquisition. Conversely, returnees who originally migrated to Iran compared to Pakistan are more likely to be involved in farming or herding upon return. The same is true regarding the number of years since return and the amount of savings brought back, although all are only marginally statistically significant at the $10 \%$ level. Lastly, individuals having received assistance upon return and with concrete intentions to re-migrate are less likely to be occupied with agriculture. We believe this indicates labor-intensive activities such as farming or herding animals may necessitate high upfront investment in productive assets like land and livestock not covered by the support received but which makes future movement less desirable.

\section{Conclusion}

The reintegration into the local labor market is a key element of the sustainable return of refugees in (post-)conflict settings. Yet the income-generating 
Table 3 Labor market activity, comparing non-migrants to returned refugees

\begin{tabular}{|c|c|c|c|c|c|c|}
\hline \multirow[b]{2}{*}{ Base:not working } & \multicolumn{3}{|l|}{ Non-migrant } & \multicolumn{3}{|c|}{ Returned refugee } \\
\hline & $\begin{array}{l}\text { Self- } \\
\text { employment }\end{array}$ & Agriculture & $\begin{array}{l}\text { Wage } \\
\text { employment }\end{array}$ & $\begin{array}{l}\text { Self- } \\
\text { employment }\end{array}$ & Agriculture & $\begin{array}{l}\text { Wage } \\
\text { employment }\end{array}$ \\
\hline \multirow[t]{2}{*}{ Head of HH } & $4.4075^{* * *}$ & $5.3701 * * *$ & $4.7482 * * *$ & $4.8621 * *$ & 3.6079 & $5.7055 * *$ \\
\hline & -1.0821 & -1.7967 & -1.2748 & -3.0015 & -2.8974 & -4.8777 \\
\hline \multirow[t]{2}{*}{ Age } & $0.9464 * * *$ & $0.9617 * * *$ & $0.9478 * * *$ & $0.9381 * * *$ & $0.9634 *$ & $0.9501 * * *$ \\
\hline & -0.0087 & -0.0111 & -0.0094 & -0.015 & -0.0188 & -0.0167 \\
\hline \multirow[t]{2}{*}{ Married } & $3.3443 * * *$ & $3.1959 * * *$ & $2.5051 * * *$ & 2.7105 & 2.7101 & 1.9905 \\
\hline & -0.8405 & -1.1225 & -0.657 & -1.9118 & -2.535 & -1.7207 \\
\hline \multirow[t]{2}{*}{ Number of children } & $0.9130 * *$ & 0.9906 & 0.9446 & 1.0858 & 1.0204 & 1.1387 \\
\hline & -0.0418 & -0.0604 & -0.0471 & -0.0908 & -0.1072 & -0.1041 \\
\hline \multirow[t]{2}{*}{ Education: secondary or higher } & $0.6148^{*}$ & $0.2753 * *$ & $2.8348^{* * *}$ & 0.8992 & $0.1652 * *$ & 2.2920 \\
\hline & -0.1721 & -0.1707 & -0.8252 & -0.3872 & -0.1254 & -1.0599 \\
\hline \multirow[t]{2}{*}{ HH owns land } & 0.9018 & $3.9817 * * *$ & 0.9534 & 1.7468 & $11.3484 * * *$ & 0.855 \\
\hline & -0.2044 & -1.03 & -0.2276 & -0.7893 & -5.8669 & -0.4509 \\
\hline \multirow[t]{2}{*}{ Community involvement } & $2.3039 * * *$ & $2.6049 * * *$ & $2.0563 * * *$ & $2.9124 * * *$ & $3.3171 * *$ & $2.8980 * * *$ \\
\hline & -0.4655 & -0.7477 & -0.433 & -1.112 & -1.9121 & -1.1689 \\
\hline Pseudo- $\mathrm{R}^{2}$ & 0.2177 & & & 0.2118 & & \\
\hline $\mathrm{N}$ & 1380 & & & 461 & & \\
\hline
\end{tabular}

Significance levels: $* p<0.10, * * p<0.05$, *** $p<0.01$. Relative risk ratios are reported, with robust standard errors in parentheses. The reference group for educational attainment is "lower than secondary." Other controls not reported include "Ethnicity," "District type," and "Province"

activities of such populations upon return, and particularly the role of self-employment, are not well understood. Literature on the return of labor migrants has shown that returnees have a higher likelihood of being self-employed in contrast to wage employment than their non-migrant counterparts. Similar studies looking at the return of forced migrants, on the other hand, are lacking. Utilizing a unique data set, this paper therefore investigates the labor market outcomes of returned refugees in Afghanistan, a country that has been characterized by conflict and general insecurity for decades.

The results of the analysis show that returned refugees are less likely to be wage employed in comparison to non-migrants, and differences in labor market outcomes seem to arise primarily from dissimilarities in socioeconomic status. For example, non-migrants with higher levels of schooling are more likely to be in waged labor, whereas labor market activities have less to do with educational attainment for returnees. As such, we can deduce that those individuals of a higher socioeconomic status are generally able to take advantage of the insufficient employment opportunities available, yet having left the country and since returned limits any such ability. On the other hand, having social capital within the local community, proxied for by community involvement, helps both non-migrants' and returnees' chances of being engaged in all labor market activities similarly.

As for the influence of the migration and return experience on labor market outcomes, a few key factors are found to be of consequence. First, and somewhat expectedly, being employed prior to migrating helps raise the likelihood of being wage employed upon return. Less expected, however, given the context of forced migration, the more years spent abroad the greater the odds of being wage employed pointing to skill acquisition. Moreover, and likely corresponding to the prior notion related to socioeconomic status, those who received financial assistance to return from either an international organization or government program are less likely to be involved in agriculture as well as wage employed. On the other hand, the amount of savings brought back upon return is beneficial when it comes to agriculture or herding, highlighting the importance of financial capital for engaging in such activities. Finally, individuals with concrete intentions to re-migrate are 
Table 4 Labor market activity for returnees, with migration and return experience

\begin{tabular}{|c|c|c|c|}
\hline Base: not working & Self-employment & Agriculture & Wage employment \\
\hline \multirow[t]{2}{*}{ Employed pre-migration } & 1.0656 & 0.3563 & $2.1744 * *$ \\
\hline & -0.4277 & -0.2324 & -0.9228 \\
\hline \multirow[t]{2}{*}{ Migration duration (years) } & 1.0342 & 1.0031 & $1.0479 *$ \\
\hline & -0.0264 & -0.0389 & -0.0298 \\
\hline \multicolumn{4}{|l|}{ Migration destination } \\
\hline \multirow[t]{2}{*}{ Iran } & 0.831 & $10.2048 * *$ & 1.7203 \\
\hline & -0.4893 & -10.4416 & -1.019 \\
\hline \multirow[t]{2}{*}{ Remittances sent } & 0.9843 & 1.3304 & 0.1693 \\
\hline & -0.851 & -1.4124 & -0.2071 \\
\hline \multicolumn{4}{|l|}{ Return period } \\
\hline \multirow[t]{2}{*}{$2002-2011$} & 0.5023 & 1.0911 & 0.9115 \\
\hline & -0.275 & -0.7591 & -0.5451 \\
\hline \multirow[t]{2}{*}{ Time since returned (years) } & 1.0092 & $1.1223 *$ & 1.0449 \\
\hline & -0.056 & -0.0822 & -0.0646 \\
\hline \multirow[t]{2}{*}{ Return reason: political/security } & 0.6685 & 0.979 & 0.9114 \\
\hline & -0.2608 & -0.4874 & -0.3816 \\
\hline \multirow[t]{2}{*}{ Return savings (log of USD) } & 1.1102 & $1.1884 *$ & 0.9854 \\
\hline & -0.0789 & -0.1143 & -0.0778 \\
\hline \multirow[t]{2}{*}{ Return assistance } & 0.6446 & $0.3509 * *$ & $0.5031 *$ \\
\hline & -0.2323 & -0.18 & -0.2069 \\
\hline \multirow[t]{2}{*}{ Re-migration intentions } & 1.803 & $0.2808 * *$ & 1.2658 \\
\hline & -0.9119 & -0.2015 & -0.6818 \\
\hline Pseudo- $\mathrm{R}^{2}$ & 0.2680 & & \\
\hline $\mathrm{N}$ & 461 & & \\
\hline
\end{tabular}

Significance levels: $* p<0.10, * * p<0.05, * * * p<0.01$. Relative risk ratios are reported, with robust standard errors in parentheses. The reference group for Migration destination is "Pakistan"; and for Return period is "1992-2001." Results for the full model provided upon request

less likely to be occupied with agriculture or herding, indicating labor-intensive activities such as farming necessitate greater investment in land and assets including livestock, making future movement less desirable.

Taking a step back from our findings, it is important to consider the evolving context related to migration from and return to Afghanistan since the data was collected in 2011. As Fig. 1 shows, return flows increased once again in 2016 in great part due to a changing policy environment toward Afghans in Pakistan, as well as a rise in forced returns from Europe. Therefore, even though the data used in the analysis may be relatively dated, the fundamental issues addressed are arguably just as relevant today as they were a few years ago.

In terms of policy, the findings imply a number of opportunities to assist small business creation by returnees in Afghanistan with the goal of supporting sustainable return and reintegration. When considering potential interventions, however, it is necessary to emphasize proper targeting and a logical focus on areas of high return. Programs already providing basic support to returnees (e.g., shelter assistance) currently operate in several provinces known for high rates of return including Nangarhar, Kabul, and Lagham in the east, Kandahar in the south, and Herat in the west (MGSoG and Samuel Hall 2013). Beyond targeting though, it is also important that assistance be meaningful to the localized context of the recipient. Unsurprisingly, individuals in rural areas are more likely to become self-employed in agriculture than in business. As such, in-kind assistance like tools, seeds, or livestock are likely to enable and support these agricultural activities, whereas assistance like business training may be more appropriate in an urban context. 
Given the role of social networks highlighted in our study, assistance focused on helping returnees build strategic linkages in their communities may be particularly beneficial. The capacity of return migrants, for instance, could be improved by bringing them in touch with other actors like business associations or a network of experts. Indeed a now-outdated program run by the Dutch IntEnt Foundation providing support to Afghan return migrants from the Netherlands had an extensive network at origin willing to help newcomers by sharing knowledge, contacts, and in some cases even investments (de Haas 2006). Moreover, a similar and currently ongoing program by the German Development Cooperation has proven to be beneficial to return migrants wanting to open a business in several developing countries and emerging market economies, for example, Morocco, Cameroon, Ghana, Senegal and Nigeria in Africa or Ecuador, and Colombia and Peru in Latin America (CIM 2018). Additionally, our finding concerning the importance of savings suggests a possible credit constraint at home which earnings from abroad help to ease. With this in mind, small grants and/or loans for the purpose of investing in a business venture may be a viable strategy if provided to a suitable recipient with practical ideas and the capacity to carry them out. Careful selection is therefore important to increase the likelihood of effective implementation, but certain conditions could be put in place to help improve the odds of success including mandatory attendance to training session or membership in a business group.

Above all, reintegration into the labor market is an important step in the process of sustainable return to a (post-)conflict environment like that of Afghanistan. In a context where wage employment is systematically limited however, self-employment may simply be the only if not best viable income-generating activity. Providing support then to returned refugees for this specific purpose, whether for a business venture or agricultural endeavor, has the potential to not only facilitate reintegration and improve individual welfare but also contribute to local development.

Open Access This article is licensed under a Creative Commons Attribution 4.0 International License, which permits use, sharing, adaptation, distribution and reproduction in any medium or format, as long as you give appropriate credit to the original author(s) and the source, provide a link to the Creative Commons licence, and indicate if changes were made. The images or other third party material in this article are included in the article's Creative Commons licence, unless indicated otherwise in a credit line to the material. If material is not included in the article's Creative Commons licence and your intended use is not permitted by statutory regulation or exceeds the permitted use, you will need to obtain permission directly from the copyright holder. To view a copy of this licence, visit http://creativecommons.org/licenses/by/4.0/.

\section{References}

Ács, Z. (2006). How is entrepreneurship good for economic growth? Innovations: Technology, Governance, Globalization, 1(1), 97-107.

Arif, G. M., \& Irfan, M. (1997). Return migration and occupational change: The case of Pakistani migrants returned from the Middle East. The Pakistan Development Review, 36(1), 1-37.

Bascom, J. (2005). Last step? Reintegration of repatriates in Eritrea. Journal of Refugee Studies, 18(2), 165-180.

Bjelica, J. \& Ruttig, T. (2017). Voluntary and forced returns to Afghanistan in 2016/17: Trends, statistics and experiences. Afghanistan Analysts Network. Retrieved from $<$ https://www.afghanistan-analysts.org/voluntary-andforced-returns-to-afghanistan-in-201617-trends-statisticsand-experiences/>.

Black, R., \& Castaldo, A. (2009). Return migration and entrepreneurship in Ghana and Cote D'Ivoire: The role of capital transfers. Tijdschrift voor Economische en Sociale Geografie, 100(1), 44-58.

Black, R., \& Gent, S. (2006). Sustainable return in post-conflict contexts. International Migration, 44(3), 15-38.

Black, R., King, R., \& Tiemoko, R. (2003). Migration, return and small enterprise development in Ghana: A route out of poverty? Sussex Migration working no. 9. Sussex Centre for Migration Research, University of Sussex.

Borodak, D., \& Piracha, M. (2011). Occupational choice of return migrants in Moldova. Eastern European Economics, 49(4), 24-46.

Bosma, N., van Praag, M., Thurik, R., \& de Wit, G. (2004). The value of human and social capital investments for the business performance of startups. Small Business Economics, 23(3), 227-236.

Cassarino, J. P. (2004). Theorising return migration: The conceptual approach to return migrants revisited. International Journal of Multicultural Societies, 6(2), 253-279.

Central Statistics Office (CSO). (2014). National Risk and Vulnerability Assessment 2011/2012. Afghanistan living conditions survey. Kabul: Central Statistics Office.

Centrum für internationale Migration und Entwicklung (CIM). (2018). Business ideas for development. Retrieved from $<$ https://www.cimonline.de/en/html/business-ideas.html>

Ciarli, T., Parto, S., \& Savona, M. (2010). Conflict and entrepreneurial activity in Afghanistan: Findings from the national risk and vulnerability assessment data. Working paper no. 2010/08. Helskinki: UNU-WIDER.

Collier, P. (2009). Post-conflict recovery: How should strategies be distinctive? Journal of African Economies, 18(suppl_1), i99-i131.

Cramer, C. (2015). Peace work: Labour markets, work and violence. UNDP Human Development Report Office Think Piece. New York: UNDP. 
de Haas, H. (2006). Engaging diasporas. How governments and development agencies can support diaspora involvement in the development of their origin countries. A study for Oxfam Novib, Oxford: International Migration institute, University of Oxford.

de Haas, H. (2016). Refugees: A small and relatively stable proportion of world migration [Blog post]. Retrieved from $<$ http://heindehaas.blogspot.com.es/2016/08/refugees-smalland-relatively-stable.html>.

de Vreyer, P., Gubert, F., \& Robilliard, A. S. (2010). Are there returns to migration experience? An empirical analysis using data on return migrants and non-migrants in West Africa. Annals of Economics and Statistics, 97/98, 307-328.

Desai, S. (2011). Measuring entrepreneurship in developing countries. In W. Naudé (Ed.), Entrepreneurship and economic development (pp. 94-107). Basingstoke: Palgrave Macmillan.

Dustmann, C., \& Kirchkamp, O. (2002). The optimal migration duration and activity choice after re-migration. Journal of Development Economics, 67(2), 351-372.

Gubert, F., \& Nordman, C. J. (2011). Return migration and small enterprise development in the Maghreb. In S. Plaza \& D. Ratha (Eds.), Diaspora for Development in Africa (pp. 103126). Washington D. C.: World Bank.

Hautaniemi, P., Juntenen, M., \& Sato, M. (2013). Return migration and vulnerability: Case studies from Somaliland and Iraqi Kurdistan. Helsinki: Interkont Books.

Human Rights Watch (2017). Pakistan: Mass forced returns of afghan refugees. UN Refugee Agency Complicit in Government Coercion. Retrieved from <https://www.hrw. org/news/2017/02/13/pakistan-mass-forced-returnsafghan-refugees $>$.

Ilahi, N. (1999). Return migration and occupational change. Review of Development Economics, 3(2), 170-186.

ILO. (2013). Assessment of livelihood opportunities for the returnees/IDPs and the host communities. Geneva: ILO.

IOM. (2017). Return of undocumented Afghans from Pakistan and Iran. 2016 Overview. Geneva: IOM.

Kilic, T., Carletto, C., Davis, B., \& Zezza, A. (2009). Investing back home: Return migration and business ownership in Albania. The Economics of Transition, 17(3), 587-623.

Klagge, B., Klein-Hitpas, K., Fihel, A., Kindler, M., Matejko, E., \& Okolski, M. (2007). High-skilled return migration and knowledge-based economic development in a regional perspective: Conceptual considerations and the example of Poland. CMR working paper 19. Centre of Migration Research, Warsaw University.

Kuschminder, K. (2013). Female return migration and reintegration strategies in Ethiopia. Maastricht: MGSoG.

Maastricht Graduate School of Governance (MGSoG) \& Samuel Hall Consulting. (2013). Evaluation of the UNHCR shelter assistance programme: Full report. Maastricht: MGSoG.

Margolis, D. N. (2014). By choice and by necessity: Entrepreneurship and self-employment in the developing world. European Journal of Development Research, 26(4), 419-436.
McCormick, B., \& Wahba, J. (2001). Overseas work experience, savings and entrepreneurship amongst return migrants to LDCs. Scottish Journal of Political Economy, 48(2), 164 178.

Mesic, M., \& Bagic, D. (2011). Minority return to Croatia: Study of an open process. Geneva: UNHCR.

Mesnard, A. (2004). Temporary migration and capital market imperfections. Oxford Economic Papers, 56(2), 242-262.

Nagler, P. (2015). Occupational Choice in the developing world. Maastricht: MGSoG.

Naudé, W. (2010a). Entrepreneurship, developing countries, and development economics: New approaches and insights. Small Business Economics, 34(1), 1-12.

Naudé, W. (2010b). Promoting entrepreneurship in developing countries. In Policy brief 4. UNU-WIDER: Helsinki.

Novak, P. (2007). Place and Afghan refugees: A contribution to Turton. Journal of Refugee Studies, 20(4), 551-578.

OECD. (2008). International Migration outlook. Paris: OECD.

OECD. (2010). Entrepreneurship and migrants - report by the OECD working party on SMEs and entrepreneurship. Paris: OECD.

Omata, N. (2012). Repatriation and integration of Liberian refugees from Ghana: The importance of personal networks in the country of origin. Journal of Refugee Studies, 26(2), 265-282.

Piracha, M., \& Vadean, F. (2010). Return migration and occupational choice: Evidence from Albania. World Development, 38(8), 1141-1155.

Reynolds, P. D., Bosma, N., Autio, E., Hunt, S., De Bono, N., Servais, I., Lopez-Garcia, P., \& Chin, N. (2005). Global entrepreneurship monitor: Data collection design and implementation 1998-2003. Small Business Economics, 24(3), 205-231.

Stewart, F. (2015). Employment in conflict and post-conflict situations. UNDP human development report office think piece. New York: UNDP.

Tani, M., \& Mahuteau, S. (2008). Return migration and working choices. MIREM project analytical report 1. Robert Schuman Centre for Advanced Studies, European University Institute.

UNHCR. (2018a). Global trends: Forced displacement in 2017. Geneva: UNHCR.

UNHCR (2018b). UNHCR statistical online population database. Retrieved from <http://popstats.unhcr.org $>$. Geneva: UNHCR.

Wahba, J., \& Zenou, Y. (2012). Out of sight, out of mind: Migration, entrepreneurship and social capital. Regional Science and Urban Economics, 42(5), 890-903.

Westlund, H., \& Bolton, R. (2003). Local social capital and entrepreneurship. Small Business Economics, 21(2), 77-113.

Zenou, Y. (2008). Job search and mobility in developing countries. Theory and policy implications. Journal of Development Economics, 86(2), 336-355.

Publisher's note Springer Nature remains neutral with regard to jurisdictional claims in published maps and institutional affiliations. 